\title{
Identification of QTL FBF7 fire blight resistance in apple varieties germplasm
}

\author{
Alexander Lyzhin*, and Natalya Saveleva
}

Federal State Scientific Institution «I. V. Michurin Federal Scientific Center», 30 st. Michurina, Michurinsk, 393774

\begin{abstract}
This paper describes the results of marker-mediated screening of apple varieties for QTL FBF7 fire blight resistance. We detected at least one marker out of three in 12 varieties $(85.7 \%)$ and two markers out of three in 5 varieties $(35.7 \%)$. The target fragments of the studied markers in the Antonovka obiknovennaya and Galarina varieties are missing. Indicating the presence of QTL FBF7 three markers (GE-8019, AE10-375 and $\mathrm{CH}-\mathrm{F} 7-\mathrm{Fb} 1)$ were identified in the Bylina, Rozhdestvenskoe, Uspenskoe and Charodeyka varieties, which we recommend for use in breeding for E. amylovora resistance.
\end{abstract}

Fire blight of fruit crops (bacteria Erwinia amylovora (Burill) Winslow et al.) is a dangerous plant disease, including apple trees. It is widely distributed in many countries of the world $[1,2]$.

Due to rapid spread in fruit plantations, the harmfulness of fire blight is very high. Under favorable conditions, the mass development of E. amylovora can lead of entire gardens to death [3].

Using of synthetic antibiotics in fruit crops is only one way to control the spread of $E$. amylovora until now. Such an active use of chemical protective agents adversely affects the environmental situation, and can contribute to the E. amylovora highly resistant strains appearance $[4,5]$. Therefore, using the genetically resistant to E. amylovora varieties is a promising way to combat the fire blight in fruit crops $[6,7]$.

Fire blight resistance controlled by quantitative trait loci (QTL) has been identified in various wild apple species and varieties. Many of them have also scab and powdery mildew genetic resistance, which is very important too. Individual QTLs from the original wildgrowing species were subsequently introgressed into the cultivated forms germplasm [8$11]$.

QTL FBF7 is one of the largest QTLs that control apple trees fire blight resistance. It was mapped on the 7th chromosome of the Fiesta variety $[12,13]$.

This study presents the results of apple varieties marker-mediated screening for fire blight resistance. (QTL FBF7).

The study was conducted in 2020-2021. Apple varieties of the FSSI «I.V. Michurin Federal Scientific Center» genetic collection were used as biological objects (Table 1).

${ }^{*}$ Corresponding author: Ranenburzhetc@yandex.ru 
Table 1. Analyzed apple varieties

\begin{tabular}{|c|c|c|}
\hline Variety & Breeding combination & Origin / Originator \\
\hline $\begin{array}{l}\text { Antonovka } \\
\text { obiknovennaya }\end{array}$ & - & Folk selection, Russia \\
\hline Bylina & $\begin{array}{l}\text { Prima } \times \text { Bessemyanka } \\
\text { michurinskaya }\end{array}$ & \multirow{6}{*}{$\begin{array}{l}\text { FSSI «I.V. Michurin Federal } \\
\text { Scientific Center», Russia }\end{array}$} \\
\hline Vimpel & Scala $\times$ Karpovskoe & \\
\hline Scala & $\begin{array}{l}\text { Prima } \times \text { Bessemyanka } \\
\text { michurinskaya }\end{array}$ & \\
\hline Uspenskoe & $\begin{array}{l}\text { Prima } \times \text { Bessemyanka } \\
\text { michurinskaya }\end{array}$ & \\
\hline Fregat & Scala $\times$ Karpovskoe & \\
\hline Charodeyka & $12-59 \times$ Vazak & \\
\hline Kandil Orlovskii & 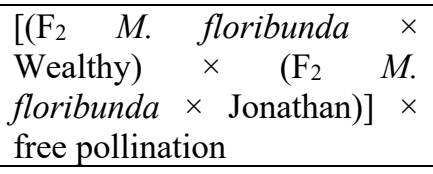 & \multirow[t]{2}{*}{$\begin{array}{l}\text { FSSI Russian Research Institute } \\
\text { of Fruit Crop Breeding, Russia }\end{array}$} \\
\hline Rozdestvenskoe & Wealthy $\times$ BM41497 & \\
\hline Gala & $\begin{array}{l}\text { Kidds Orange } \times \text { Golden } \\
\text { Delicious }\end{array}$ & J.H. Kidd, New Zealand \\
\hline Galarina & Gala $\times$ Florina & $\begin{array}{l}\text { Institut national de la recherche } \\
\text { agronomique, France }\end{array}$ \\
\hline Ligol & Linda $\times$ Golden Delicious & $\begin{array}{l}\text { Horticulture and Floriculture } \\
\text { Institute, Poland }\end{array}$ \\
\hline Lobo & Macintosh $\times$ free pollination & $\begin{array}{lll}\text { Ottawa } & \text { Experimental Station, } \\
\text { Canada } & & \\
\end{array}$ \\
\hline Fuji & Red Delicious $\times$ Rale Janet & $\begin{array}{l}\text { Tohoku Experimental Station, } \\
\text { Japan }\end{array}$ \\
\hline
\end{tabular}

Molecular markers AE10-375 (for 5'-ctgaagcgcacgttctcc-3', rev 5'ctgaagcgcatcatttctgatag-3'), GE-8019 (for 5'-ttgagaccgattttcgtgtg-3', rev 5'tctctcccagagcttcattgt-3') and $\mathrm{CH}-\mathrm{F} 7-\mathrm{Fb} 1$ (for 5'-agccagatcacatgtttcatc-3', rev 5'acaacggecaccagtttatc-3') were used to identify the QTL FBF7 apple trees fire blight resistance [14].

AE10-375 and GE-8019 markers flank QTL FBF7: AE10-375 marker is localized at a distance of $4 \mathrm{cM}$ from the QTL peak, GE-8019 marker is localized at a distance of $6 \mathrm{cM}$ from the QTL peak. CH-F7-Fb1 marker is mapped on the same side of the QTL as AE10375 and used to increase the reliability of molecular-genetic analysis $[15,16]$.

Total volume of $15 \mathrm{ml}$ of the reaction mixture was contained: $1.5 \mathrm{mM}$ Taq buffer, 2.0 $\mathrm{mM}$ deoxynucleoside triphosphates mixture, $2.5 \mathrm{mM}$ magnesium chloride, $0.2 \mu \mathrm{m}$ of each primer, $0.2 \mathrm{U}$ Taq polymerase and $20 \mathrm{ng}$ of total DNA.

The polymerase chain reaction was carried out in the T100 amplifier (BIO-RAD) in the following modes: initial denaturation of $5 \mathrm{~min}$ at $94^{\circ} \mathrm{C}$, then 35 cycles: $1 \mathrm{~min}$ at $94^{\circ} \mathrm{C}, 1.5$ $\min$ at $50^{\circ} \mathrm{C}, 1.5 \mathrm{~min}$ at $72^{\circ} \mathrm{C}$; then the final elongation of $15 \mathrm{~min}$ at $72^{\circ} \mathrm{C}$.

Amplification products separation was carried out by the electrophoretic method in an agarose gel (2\% agarose concentration, 1 x TBE buffer system). The Gene Ruler 100 bp DNA Ladder (Thermo Fisher Scientific) gene line was used to amplicon size determination.

According to the conducted studies, 210 bp allele of the CH-F7-Fb1 marker (linked to QTL FBF7 fire blight resistance) was identified in 8 out of 14 apple varieties. AE10-375 
marker (amplicon 375 bp) was identified in 12 forms, GE-8019 marker - in 5 forms (Table 2).

Table 2. Allele polymorphism of apple tree fire blight resistance (QTL FBF7) molecular markers

\begin{tabular}{|l|c|c|c|c|}
\hline \multirow{2}{*}{ Variety } & \multicolumn{4}{|c|}{ QTL FBF7 DNA markers } \\
\cline { 2 - 5 } & GE-8019 & AE10-375 & \multicolumn{2}{c|}{ CH-F7-Fb1 } \\
\cline { 2 - 5 } & $397 \mathrm{bp}$ & $375 \mathrm{bp}$ & $174 \mathrm{bp}$ & $210 \mathrm{bp}$ \\
\hline Antonovka obiknovennaya & 0 & 0 & 1 & 0 \\
\hline Bylina & 1 & 1 & 0 & 1 \\
\hline Vimpel & 0 & 1 & 1 & 0 \\
\hline Gala & 0 & 1 & 1 & 0 \\
\hline Galarina & 0 & 0 & 1 & 0 \\
\hline Kandil Orlovskii & 0 & 1 & 1 & 0 \\
\hline Ligol & 0 & 1 & 0 & 1 \\
\hline Lobo & 1 & 1 & 1 & 0 \\
\hline Rozdestvenskoe & 1 & 1 & 0 & 1 \\
\hline Scala & 0 & 1 & 0 & 1 \\
\hline Uspenskoe & 1 & 1 & 0 & 1 \\
\hline Fregat & 0 & 1 & 0 & 1 \\
\hline Fuji & 0 & 1 & 0 & 1 \\
\hline Charodeyka & 1 & 1 & 0 & 1 \\
\hline
\end{tabular}

At least one marker out of three was detected in most of the analyzed apple varieties (85.7\%). Two markers out of three were present in 5 varieties (35.7\%): Lobo variety has GE-8019 and AE10-375 markers, Ligol, Skala, Fregat, Fuji varieties have AE10-375 and $\mathrm{CH}-\mathrm{F} 7-\mathrm{Fb} 1$ markers.

The target fragments of the studied markers are absent in the Antonovka obiknovennaya and Galarina varieties.

Three markers indicating the presence of QTL FBF7 fire blight resistance were identified in the genome of the Bylina, Rozhdestvenskoe, Uspenskoe and Charodeyka varieties. QTL flanking markers GE-8019 and AE10-375 (CH-F7-Fb1 marker is absent) were detected in the Lobo variety. Presumably, that also indicates the presence of QTL FBF7 with less probability than in the presence of three markers.

After analyzing apple varieties for fire blight resistance using molecular markers, we came to the following conclusions. Linked to the QTL FBF7 GE-8019, AE10-375 and CHF7-Fb1 markers were identified in Bylina, Rozhdestvenskoe, Uspenskoe and Charodeyka varieties. We recommend these varieties for use in breeding for E. amylovora resistance.

\section{References}

1. I. Schlathölter, M. Jänsch, H. Flachowsky, G.A.L. Broggini, M.V. Hanke, A. Patocchi, Planta, 247(6), 1475-1488 (2018) https://doi.org/10.1007/s00425-018-2876-Z

2. S.A. Kostick, J.L. Norelli, K.M. Evans, Plant Pathol., 68(5), 985-996 (2019) https://doi.org/10.1111/ppa.13012

3. P.J. Jensen, N. Halbrendt, G. Fazio, I. Makalowska, N. Altman, C. Praul, S.N. Maximova, H.K. Ngugi, R.M. Crassweller, J.W. Travis, T.W. McNellis, BMC genomics, 13(1), 9 (2012) https://doi.org/10.1186/1471-2164-13-9

4. S.G. Aćimović, Q. Zeng, G.C. McGhee, G.W. Sundin, J.C. Wise, Front. Plant Sci., 6, 16 (2015) https://doi.org/10.3389/fpls.2015.00016 
5. S. Jarolmasjed, S. Sankaran, A. Marzougui, S. Kostick, Y. Si, J.J. Quirós Vargas, K. Evans, Front. Plant Sci. 10, 576 (2019) https://doi.org/10.3389/fpls.2019.00576

6. S.A. Kostick, S.L. Teh, J.L. Norelli, S. Vanderzande, C. Peace, K.M. Evans, Hortic. Res., 8, 28 (2021) https://doi.org/10.1038/s41438-021-00466-6

7. R. Testolin, L. Falginella, A. De Carli, G. De Mori, G. Cipriani, Italus Hortus 28, 32-43 (2021) https://doi.org/10.26353/j.itahort/2021.1.3243

8. T.D. Kost, C. Gessler, M. Jänsch, H. Flachowsky, A. Patocchi, G.A.L. Broggini, PLoS ONE, 10(12), e0143980 (2015) https://doi.org/10.1371/journal.pone.0143980

9. N.I. Savel'ev, A.S. Lyzhin, N.N. Savel'eva, Russ. Agricult. Sci., 42, 310-313 (2016) https://doi.org/10.3103/S1068367416050189

10. J.M. Harshman, K.M. Evans, H. Allen, R. Potts, J. Flamenco, H.S. Aldwinckle, M.E. Wisniewski, J.L. Norelli, Plant Dis., 101(10), 1738-1745 (2017) https://doi.org/10.1094/PDIS-01-17-0077-RE

11. A.S. Lyzhin, N.N. Savel'eva, Proceedings of the National Academy of Sciences of Belarus - Agrarian Series, 59(1), 62-70 (2021) https://doi.org/10.29235/1817-72042021-59-1-62-70

12. M. Kellerhals, I.O. Baumgartner, L. Leumann, J.E. Frey, A. Patocchi, Acta Hortic., 976, 487-491 (2013) https://doi.org/10.17660/ActaHortic.2013.976.68

13. D. Papp, Z. Békefi, B. Balotai, M. Tóth, Plant Breed., 134(3), 345-349 (2015) https://doi.org/10.1111/pbr.12258

14. I.N. Shamshin, M.V. Maslova, N.V. Drenova, M.L. Dubrovsky, O.V. Parusova, Proceedings on applied botany, genetics and breeding, 181(4), 185-191 (2020) https://doi.org/10.30901/2227-8834-2020-4-185-191

15. I.O. Baumgartner, A. Patocchi, J.E. Frey, A. Peil, M. Kellerhals, Plant Mol. Biol. Rep., 33(5), 1573-1583 (2015) https://doi.org/10.1007/s11105-015-0858-X

16. H. Nybom, A. Mikiciński, L. Garkava-Gustavsson, J. Sehic, M. Lewandowski, P. Sobiczewski, Trees 26(1), 199-213 (2012) https://doi.org/10.1007/s00468-011-0649-4 